\title{
Noreg og dei polskjødiske flyktningane, 1968-1970
}

\author{
Svein-Erik Larsen
}

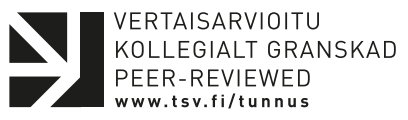

DOI: https://doi.org/10.30752/nj.101743

\begin{abstract}
Aвstract - In i 968, an antisemitic campaign, launched by the Polish government, caused around I 3 ,000 Jews to leave Poland. About 2500 of these refugees came to Denmark, while only about 25 ended up in Norway. The migration to Norway could potentially have reached low hundreds, but as oral-history sources indicate, the Jewish congregation in Oslo turned down a government initiative in 1969 . Based on written and oral sources, and secondary literature, I argue that there was an equally important factor differentiating the two countries. Comparing the Danish and Norwegian refugee reception policies, the article finds that Danish authorities and their NGO partners at decisive stages in the process were more proactive than their Norwegian counterparts in their efforts to persuade Polish Jews to come. The most critical point was in June I 969, when Denmark's embassy in Warsaw started issuing Jews with automatic visas, while Norway retained its existing application process.
\end{abstract}

\section{Innleiing}

6. oktober I 968 skreiv Aust-Europa-korrespondenten i Arbeiderbladet, Dag Halvorsen, eit brev frå Praha. Essensen i brevet var at sjølv om den antisionistiske kampanjen i Polen offisielt var avblåst, kunne fortrulege kjelder stadfeste at jødar framleis blei avsette frå stillingane deira og sjikanert av både politi og myndigheiter. Brevet blei sendt til nøkkelpersonar innan regjering, parlament, utanriksteneste, media og andre samfunnstoppar i Noreg, Sverige og Danmark. Halvorsen appellerte til dei skandinaviske landa sine humanitære tradisjonar med oppfordringa om å la jødar reise til Norden. Omstenda gjorde det nødvendig å vise førutsigbarheit og diskresjon (Smedegaard Pedersen 2005: 26-27). Dette brevet fekk forskjellege følgjer i Noreg, der berre cirka 25 polskjødiske flyktningar kom, enn Sverige og Danmark, der det kom cirka 5000 til saman. Den ulike mottakinga av polskjødiske flyktningar i dei tre landa er eit tema, som fram til nyleg knapt var omtala $\mathrm{i}$ norsk historieskriving. Blant anna blei det ikkje omtala $\mathrm{i}$ trebindsverket «Norsk innvandringshistorie». Dette reagerte Einhart Lorenz på i bokmeldinga si i Historisk Tidsskrift:
Hvorfor Norge, i motsetning til Sverige og Danmark, ikke tok imot polsk-jødiske flyktninger etter de antisemittiske bølgene i 1956 og I 968 , forblir ubesvart. For meg hadde vært interessant å vite om dette skyldtes mer enn den geografiske avstan- den. (Lorenz 2006: I 34).

Arkivmaterialet viser at personar i den norske utanrikstenesta stilte seg liknande spørsmål allereie i samtida under I 968-bølgja som 
denne artikkelen skal omhandle. ${ }^{1}$

Jødar har ei historie i Noreg tilbake til slutten av I80o-talet, men antisemittisme sin historie i landet er enda lenger. Antisemittiske haldningar blant riksforsamlinga på Eidsvoll i I 8 I4, førte til at det blei grunnlovsfesta eit forbod (oppheva i 185 I) mot jødisk åtgang til riket. Norske jødar blei brutalt råka under andre verdskrig. Alle jødar som var i Noreg då Tyskland invaderte landet 9. april r 940 blei enten deporterte eller flykta, hovudsakleg til Sverige. 766 norske jødar blei drepne grunna nazistanes utrydningspolitikk (Rømming 2018). Etter krigen måtte returnerande jødar bygge opp Noregs jødiske miljø på nytt. På slutten av r 940-talet kom det ei organisert mottak av Holocaustoverlevande jødiske flyktningar til Noreg frå Tyskland og Polen. Erfaringane frå krigen og etterkrigsmottaket var svært sentrale for Noregs jødiske miljø i I 968. Den som hatt størst betydning for norsk jødisk historieforsking er Oskar Mendelsohn, særleg gjennom det altomfattande verket «øødenes historie i Norge gjennom 300 år», men heller ikkje han gjekk djupare inn i kvifor det ikkje kom fleire polskjødiske flyktningar til Noreg

1 Denne oppgåva er i stor grad basert på mi masteroppgåve våren 2020 som kjeldeinnsamlinga blei gjort til «Noreg og dei polskjødiske flyktningane, I960-I 970» (Larsen 2020). Der plasserte eg tidspunktet for myndigheitene sin førespurnad til Det Mosaiske Trossamfund i Oslo til februar I970 basert på at siste teikn til planlegging var i januar, men i denne oppgåva er det korrigert til slutten av april I 969 basert på Zofia Paszkiewiczs NRK-artikkel «ødene Norge ikke ønsket» (2020). Ho forklarte meg at utifrå samtalane med intervjuobjekt meinte ho dette måtte ha skjedd før eit møtet med Ted Feder i mai r 969. Utifrå kommunikasjonen mellom ambassaden og UD tidfesta ho dette til april I 969. Dette påverkar argumentasjonen i artikkelen, og skil den frå masteroppgåva. frå r 968. Med å undersøke kvifor den jødiske emigrasjonen frå Polen ikkje førte til større immigrasjon til Noreg skal eg sette søkelys på ein uutforska del av jødisk historie i Noreg, og norsk innvandringshistorie.

For å utforske Lorenz sin etterspørsel støyter eg på eit metodisk problem: Korleis finne årsaka til noko som ikkje skjedde? Løysinga eg har valt er å bruke komparativ metode. Ein komparativ analyse hever perspektivet, samanlikna med kva ein analyse av berre den norske case kunne gjere. John Stuart Mill skilde mellom method of difference (forskjellsmetoden) og method of similarities (samsvarsmetoden) som eksempel på korleis ei systematisk samanlikning ofte kan byggast opp. Sidan eg skal forklara forskjellar, er det forskjellsmetoden som blir aktuell. Eg skal jakte på likskapar og forskjellar for å sjå om eg kan finne ein avgjerande forskjell, eller eit sett av forskjellar, som kan forklare dei forskjellege utfalla (Andresen mfl. 2015: I37). For å finne samanlikningsgrunnlag returnerer eg til Lorenz sin etterspørsel. Grunna blant anna liknande befolkningsstorleik, og at begge landa blei invadert under krigen, vel eg Danmark. Denne analysen skal følgeleg utforske kva som kan forklare at det ikkje kom eit større tal polskjødiske flyktningar til Noreg, slik som Danmark, mellom I 968 og I970.

Det har blitt skrive ein del forskingslitteratur om kampanjen i Polen og den polskjødiske migrasjonen til Danmark. Dariusz Stola er blant dei viktigaste historieforskarane på den antisemittiske kampanjen i 1968. Stola er kjent for forsking om den politiske- og sosiale historia til Polen i det tjuande hundreåret, polsk-jødiske relasjonar og Holocaust, internasjonal migrasjon og kommunistregimet (Academia 20I9). Kva gjeld migrasjonen til Danmark, har Rikke Smedegaard Pedersen gjort den mest omfattande forskinga. Talfestinga av jødiske 
emigrantar frå Polen, og kor mange av dei som kom til Danmark, varierer innan forskingslitteratur og kjelder. Grunna deira grundige undersøkingar skal eg forhalda meg til Stola og Smedegaard Pedersen sine tal. Grunnane til at så få polskjødiske flyktningar kom til Noreg, var ikkje utforska før masteroppgåva mi i mai-, og deretter Zofia Paszkiewiczs NRK-artikkel i november 2020. Derfor fokuserte kjeldesøket mitt i hovudsak på det som skjedde i Noreg, og på Noregs ambassade i Warszawa mellom i 968 og 1970.

Forskingslitteraturen om Polen og Danmark kunne i mange tilfelle brukast som samanlikningsgrunnlag til norske reaksjonar på den polskjødiske emigrasjonen. Blant dei ulike kjeldene som blir brukte for å svare på problemstillinga, er avisartiklar, statlege dokument, arkivmateriale og intervju med to tidsvitne som er brukte som supplement til dei skriftlege kjeldene. Det eine tidsvitnet, Boleslaw Srebro, kom som polskjødisk flyktning til Noreg i r 969. Det andre tidsvitnet, Berit Reisel, var leiar av fleire jødiske ungdomsorganisasjonar i den aktuelle tidsperioden, der den eine, Jødisk Studentklubb, var spesielt sentral. Studentklubben var tilknytt menigheten Det Mosaiske Trossamfund i Oslo (DMT). Intervjua gir innsyn i perspektiva blant norske- og polske jødar. Trass mykje bra kjeldemateriale, manglar DMT sine styreprotokollar mellom i 968 og 1970 for å ha ei komplett samling for å rekonstruere hendingsforløpet. Intervju med Reisel, ei handskriven protokollbok frå DMT sitt styre med saksoversikt mellom I968 og I970, samt diverse arkivmateriale relatert til menigheten frå Riksarkivet i Oslo og Jødisk Museum i Oslo gir likevel godt grunnlag for denne rekonstrueringa.

I denne artikkelen argumenter eg for at det fanst to hovudfaktorar som påverka utfallet: DMT sin negative tilbakemelding på ein førespurnad frå norske myndigheiter om korleis dei stilte seg til at Noreg eventuelt skulle gjere eit kvotemottak av polskjødiske flyktningar i i 969, og forskjellar i myndigheitene sine reaksjonar: Danske myndigheiter og deira ikkje-statlege (NGO) samarbeidspartnarar var på avgjerande stadium i prosessen, tidlegare enn deira norske motpartar i deira aktive forsøk på å få polske jødar til å komme. Det mest avgjerande stadiet var sommaren I 969 då polske myndigheiter varsla at utreiseløyve for polske jødar ikkje ville bli gitt etter I. september. Danmark gjekk då over til å gi automatisk visum til alle jødiske søkjarar på ambassaden sin i Warszawa mens Noreg heldt på vanleg prosedyre. Det kom følgeleg ein straum av polskjødiske flyktningar til Danmark, men ikkje Noreg. Viktigheita av dette underbyggjast av at Sverige raskt følgde Danmarks liberalisering, og fekk ei liknande immigrasjonsauke.

For å fremje argumentet mitt vil eg etter bakgrunnsforteljinga presentere Noreg som innvandringsland i etterkrigstida fram mot den polske kampanjen, noko som var ein viktig del av konteksten mellom I968 og I970, og presentere den litle jødiske migrasjonen frå Polen til Noreg r 968-i97o. Deretter vil eg ta for meg dei viktigaste aktørane. Til slutt vil eg ta for meg dei viktigaste hendingane og viktigheita av desse.

\section{Den antisemittiske kampanjen i Polen 1968-1970}

Den antisemittiske bølgja i I 968 var ein statleg kampanje mot «sionisme» og «sionistane» i Polen. Ordet «sionist» blei i praksis brukt som eit substitutt før «jøde» eller «jødisk». Med jødar meiner eg i denne artikkelen personar som blei råka av kampanjen grunna den jødiske bakgrunnen sin slik antisemittar definerte dei, heller enn utav sjølvidentifikasjon. Stola talfesta emigrasjonen av personar jødisk bakgrunn som følgje av kampanjen til cirka 
I3 0oo. Dei fleste emigrantane var sekulære og assimilerte i det polske samfunnet. Oppblussinga av antisemittisme under banneret av «antisionisme» i Polen starta allereie etter seksdagarskrigen året før. Emigrasjonsbølgja starta likevel først etter at studentprotsetar i Warszawa 8. mars I 968 blei slått ned, og det partikontrollerte media hevda å ha funne ein sionistkonspirasjon som stod bak tre dagar seinare. Ein firedel av emigrantane flytta til Israel. Dei andre spreidde seg utover Vest-Europa og Nord-Amerika, og busette seg der dei hadde familie eller venner. Cirka 5000 enda i skandinaviske land som tok imot jødiske flyktningar i r 969 (Stola 2017: I79I80). Rikke Smedegaard Pedersen talfesta migrasjonen til Danmark til minimum 2600 mellom I 969 og I 973 (Smedegaard Pedersen 2005: 4).

Skyldingane mot jødar som «sionistar», og andre omfattande tiltak mot jødar under kampanjen var noko som i migrasjonsteorien blir kalla ein push-faktor innanfor dei funksjonalistiske push-pull modellane. $\mathrm{PhD}$ stipendiat i filosofi ved Universitet i Warwick Simon Gansinger oppsummerte konsekvensane av kampanjen som katastrofale for polske jødar. Innan eit år hadde partiet utvist cirka 8300 medlemmer, der av nesten alle jødar. 9000 menneske, flest av dei jødar, mista jobbane sine. I tillegg blei hundrevis kasta ut leilegheitene deira (Gansinger 20rg: 349-350). Push-pull modellane går ut på at migranten forlèt heimlandet grunna negative (push) faktorar der og migrerer til migrasjonsdestinasjonen sin grunna positive (pull) faktorar der. Stephen Castles, Hein De Haas og Mark J. Miller beskreiv push-pull modellane i boka The Age of Migration: International Population Movements in the Modern World (20I4). Push-pull modellar framhevar økonomiske, miljømessige og demografiske faktorar som antekne å skubbe folk ut av deira originale heimstad, og trekkje dei til

\section{Wikimedia Commons}

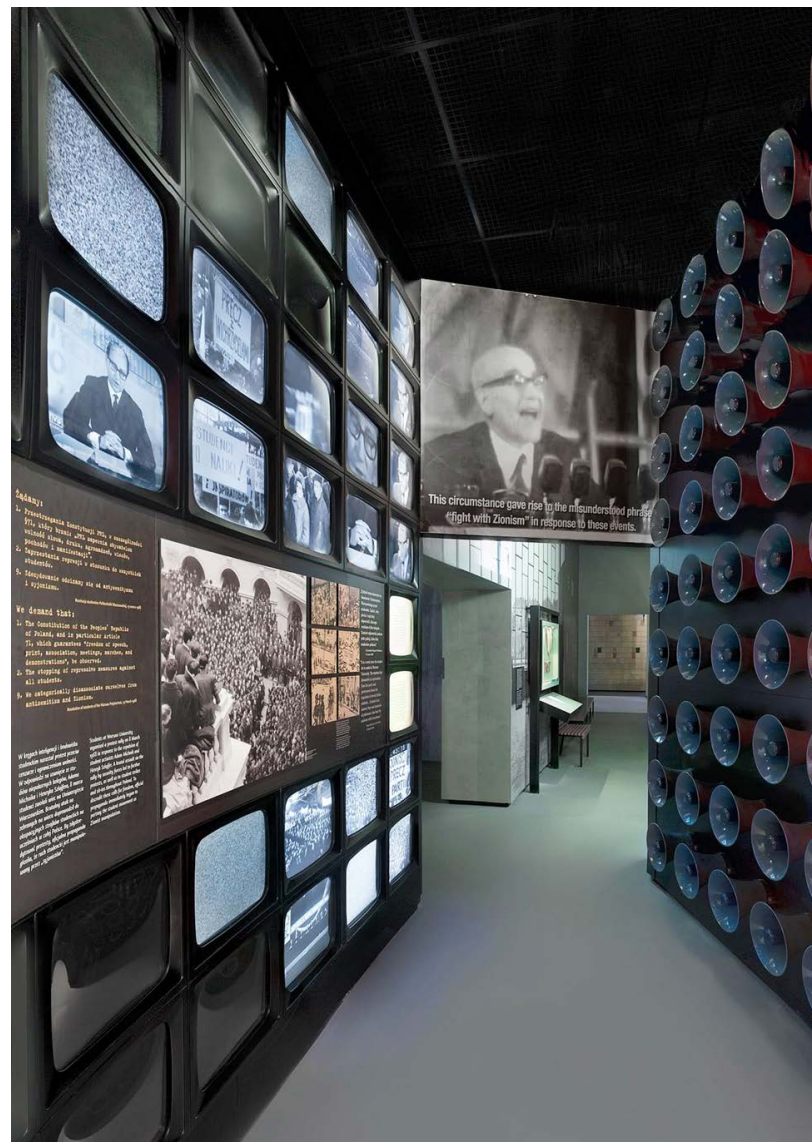

POLIN Museet for dei polske jødane si historie si utstilling om den antisemittiske kampanjen.

migrasjonsdestinasjonen (Castles mfl. 2016: 28). Eg vil hovudsakleg utforske om det fanst pull-faktorar som tiltrekte seg polske jødar som eksisterte i Danmark, men ikkje i Noreg. Kva gjeld push-faktorane som fekk jødar til å forlate Polen, vil eg fokusere rundt norske- og danske reaksjonar på desse.

Over eit år etter at kampanjen starta, kom polske myndigheiter med eit tiltak som kunne verke som ein ytterlegare push-faktor mot jødar. Varsel om stans i moglegheitene til å få utreisetillating, førte til ein ny kjapp jødisk emigrasjonsauke frå Polen sommaren I969 (Stola 2017: i 80). 9. juni hadde den kommunistiske partiavisa Trybuna Ludu ein annonse om at polakkar med jødisk bakgrunn 
berre kunne søkje om emigrasjon til Israel fram til I. september. Boleslaw Srebro beskreiv at dette skapte panikk innan det jødiske miljøet i Polen. ${ }^{2}$ Arbeiderbladet omtala haustemigrasjonen 24. september I 969 under overskrifta «300 jøder ukentlig frå Polen». Dette med ei beskriving frå Associated Press om at talet på jødar som hadde emigrert frå Polen, var komme opp i 8000 etter ein skarp auke frå sommaren. ${ }^{3}$ Varselet blei aldri overhalde. Fleire polske jødar, deriblant Srebro, emigrerte etter fristen. ${ }^{4}$ Denne fristen skapte det største skilet mellom Danmarks proaktive tilnærmingar, nemleg å gi alle jødar automatisk visum, og Noregs reaktive tilnærmingar, nemleg å halde på visumprosedyra.

\section{Danmark og Noreg: Proaktive kontra reaktive tilnærmingar}

\section{Noreg som innvandringsland}

Noreg var i 1968 eit i internasjonal kontekst rikt og homogent land, som likevel ikkje blei sett på som særleg attraktivt for potensielle immigrantar. Norsk innvandringslovgiving blei liberalisert i etterkrigstida, først innan Norden, deretter utover. Den restriktive Framandlova av 1927 blei revidert til ein meir liberal versjon i i 956. Lova si karakter av fullmaktslov blei styrkt, som betydde at mykje blei overlate til regjeringa sitt skjønn på eit fleksibelt ad hoc grunnlag. Ei nyvinning i lova var ein seksjon om politisk asyl. Ei opning for å reise inn til Noreg utan forutgåande avtale for å søke jobb opna i praksis for fri innvandring (Brochmann og Kjeldstadli 20 I4: 2 I I).

Den jødiske innvandringa til Noreg dei første etterkrigstiåra var liten, og langt frå alle blei verande i Noreg. Noregs regjering vedtok

2 Intervju med Boleslaw Srebro I I.I 2.20 I9.

3 Arbeiderbladet 24.09.1 969: 2.

4 Intervju med Boleslaw Srebro I I. I 2.20I 9. i 1946 at det skulle gjevast innreiseløyve til 600 jødar som skulle hentast frå Polen, og leirar for displaced persons i det okkuperte Tyskland. Dei allierte definerte ein displaced person som ein person som grunna krigshandlingane - med eller utan tvang - var fordrive frå heimen sin. Det blei færre då prosjekta blei realiserte. Kvoten for uttak av jødar frå leiarane i Tyskland enda på 400 under mottaksprosjektet i r 947. Blant historikarane som har undersøkt dette mottaket tettast her spesialisten på minoritetshistorie med vekt på jødisk historie Synne Corell. Ho beskreiv at det kom eit ukjent tal jødar, minst 40, til Noreg frå Polen i løpet av I 947 og I948. I 90 av personane som kom til landet i mai I 947, forlèt Noreg innan sommaren I949 (Corell 2000: I, 4, I 22).

Samarbeidet mellom myndigheitene og DMT fungerte dårleg. Verken DMT, eller norske representasjonar for organisasjonane World Jewish Congress og American Joint Distribution Committee (JDC), blei representerte i det forberedande utvalet for mottaket. Noregs statsapparat var ikkje fullstendig antisemittismefritt i tida mottaket blei gjennomført. Eksempelvis fekk ein tyskjødisk statsborgar, kjøpmann av yrke, avslag på sin søknad om innreiseløyve til Noreg for seg og kona si hausten r 946. Dette trass i at han opplyste at dei var «anerkjente ofre for fasismen». Sentralpasskontoret i Justis- og Politidepartementet utdjupa grunngjevinga for avslaget slik: «Man vil dog hvad realiteten angår tilfòie at det må være en selvfölge at det ikke skal gis innreisetilatelse til jödiske forretningsfolk» (Corell 2000: I4O-I 4I, I 53-I 54, I76-I77, I86). Flyktningane som kom blei kalla «erstatningsjødar» av den norske regjeringa, med referanse til dødstala blant norske jødar under krigen (Tangestuen 2020). Trass manglande representasjon i planlegginga fekk Den Jødiske Sosialnemnd (underorgan i DMT) ansvar for å ta hand om 
flyktningane sosialt, religiøst og økonomisk (Kieding Banik 2009: I22). Sidan DMT ikkje hadde midlar, blei storparten av midlene til sosiale formål, som eksempelvis flyktninghjelp, dekte av tilskot frå utanlandske jødiske organisasjonar. Fremst av slike var JDC, samt The Conference of Jewish Material Claims against Germany (Den jødiske samanslutnaden for materielle krav mot Tyskland) som rådde over fond til dels fått av Vest-Tyskland som ein type krigserstatning. Mendelsohn beskreiv at dette varte fram til midten av i96o-talet (Mendelsohn i 986: 453-454). Vanskane med dette mottaket var i DMT si bevisstheit i I 969 .

Flyktninginnvandringa til Noreg i etterkrigstiåra var lita og arbeidssentrert. Frå det kommunistiske kuppet i Tsjekkoslovakia i I 948, blei flyktningsituasjonen prega av kaldkrigsflyktningar som flykta til Vesten. Sosiologen Grete Brochmann og historikaren Knut Kjeldstadli beskreiv at 600 tsjekkoslovakiske flyktningar dei to følgjande tiåra utgjorde ein firedel av alle flyktningane til Noreg fram til seint på r 960-talet. Dei beskreiv vidare at på det tidlege stadiet av utvandringa/flukta frå Austblokka var ni av ti flyktningar til Noreg menn med god helse. Desse var som regel ugifte og i tjueåra, utvalde for å gli lettast mogleg inn i økonomien, med lågast moglege budsjettkostnadar. Nokre tenestemenn kalla denne gruppa «arbeidsflyktningar». I tillegg kom det også grupper på reint humanitært grunnlag beståande av 70 blinde personar som blei teke imot i r 949, og under ıoo handikappa og tuberkuløse som kom på r950- og r 960-talet. Myndigheitene kalla desse «minusflyktningar». I I 968 eksisterte det allereie presedens frå etterkrigstiåra for organiserte mottak av austeuropeiske flyktningar som rømte frå kommunistregime, som då I 500 ungararar etterkvart kom etter at Sovjetunionen slo ned opprøret i Ungarn hausten I956 (Brochmann og Kjeldstadli
20I4: 202-204). I løpet av det første halvåret hadde 200000 ungararar flykta, der av I 80000 til Austerrike og 20000 til Jugoslavia (Vekony Olsen 20r 6: r).

Norske myndigheiter hjelpte flyktningar på andre måtar enn berre ved å gje asyl. Brochmann og Kjeldstadli presenterte det flyktningspolitiske elementet som blei introdusert i den tidlege fasen av etterkrigstida, nemleg det som seinare blei kalla «beskytting i nærområdet». I starten føretrekte myndigheitene å hjelpe dei ungarske flyktningane i nærleiken av konflikten, i staden for å ta dei til Noreg. Grunngjevinga for dette var delvis basert på effektivitetsomsyn, og delvis eit ønske om å tilpasse seg flyktningane sine eigne preferansar. Utover eksterne faktorar, spelte også ei oppfatning om at Noreg ikkje hadde kapasitet til å ta imot fleire flyktningar ei rolle. Tilpassingsvanskar blant tidlege etterkrigsflyktningar hadde tidvis fătt medieomtale (Brochmann og Kjeldstadli 20I 4: 205).

Hjelpa til ungarske flyktningar i nærområdet var hovudsakleg økonomisk og kanalisertest gjennom Sosialdepartementet som skulle ha ansvar for middelfordelinga. Mottak av ungarske flyktningar blei vedteke 6 . desember 1956. Som Heidi Cecilie Vekony Olsen har vist i masteroppgåva si skyldast det fleire forhold. Flyktningstraumen var blitt så stor at Austerrike umogleg kunne handtere flyktningane aleine; myndigheitene sine utsendingar melde etter kvart om at flyktningane ønskte å komme til land lenger vekke, trass $i$ at ingen uttrykte eit spesifikt ønske om å komme til Noreg; både Danmark og Sverige hadde vedteke mottak av flyktningar. Også press frå heimleg presse, samt eit generelt press i Stortinget om å gjere meir enn berre innsatsen i nærområda, måtte ha hatt betydning (Vekony Olsen 2016: I I5-II6). Desse punkta samsvarar i stor grad med hendingsforløpet frå den jødiske emigrasjonen 
frå Polen starta i i 968. Likevel enda det ikkje med ein større migrasjon av polskjødiske flyktningar til Noreg.

Noreg nådde status som eit nettoinnvandringsland i r 967 . I r 970 var den utanlandsfødde delen av befolkninga berre to prosent, der av 42,7 prosent frå Norden (Brochmann og Kjeldstadli 2014: 202). Teknologiselskapet Knoema rangerte Noregs bruttonasjonalprodukt per innbyggar på I 2 . plass i r 968 (Knoema 2020). Same år låg norsk arbeidsløyse, OECD-området si nest lågaste mellom r 960 og I986, på I, I prosent (NAV 2or9). Også geografi verka inn på korleis potensielle immigrantar såg på Noreg. Formann i Det Norske Flyktningeråd Sigurd Halvorsen uttala i 1970 at Noreg ikkje kunne ta imot så mange flyktningar fordi landet ligg litt nær Nordpolen med ein lang og kald vinter. ${ }^{5}$ Noreg var ikkje eit attraktivt mål for migrantar i 1970 då generalsekretær i Flyktningerådet Wilhelm Bøe uttala at landet dei siste $\mathrm{I} 5$ åra hadde tatt inn dei flyktningane som hadde stranda heilt. ${ }^{6}$ Sigurd Halvorsen beskreiv at dei første flyktningane som kom etter andre verdskrig fekk isolasjonsproblem fordi dei blei spreidde for mykje, men at denne politikken var moderert i r 970. ${ }^{7}$ Denne politikken ramma også jødane som kom på r 940-talet.

\section{Polskjødisk migrasjon til Noreg 1968-1970}

Få polskjødiske flyktningar kom til Noreg som følgje av kampanjen frå i968. Oskar Mendelsohn beskreiv at berre mellom I 5 og 20 polske jødar kom til landet, trass at Statens Utlendingskontor inntok ei liberal haldning til søknadar frå desse. Han beskreiv vidare at i den første gruppa som kom til Noreg

5 Arbeiderbladet 21.05.1 970: 9.

6 Morgenbladet 26.01.1970: I2.

7 Arbeiderbladet 21.05.1970: 9. i mai I970, var det berre om lag ro jødar (Mendelsohn 1986: 383). Arkivmateriale viser at nokre få jødar kom til Noreg frå Polen allereie i r 968 og r 969. Desse, generelt velutdanna personane med kontaktnettverk, hadde personleg kontakt med Noregs ambassade i Warszawa før dei kom. Ei lista over polske jødar som hadde søkt innreiseløyve til Noreg vedlagt brev frå ambassaden til UD 8. september I 969, viste i 6 namn (alle kom ikkje nødvendigvis til Noreg) fordelte på seks familiar. ${ }^{8}$ To av desse blei omtala som professorar i eit seinare brev frå ambassaden til UD. ${ }^{9}$ I tillegg til desse to hadde Srebro og fredsforskaren Marek Thee, som kom til Noreg i i 968, profilerte akademiske karrierar. Srebro enda i Noreg som følgje av nettverksmigrasjon gjennom kontakt med ein norsk professor som hadde vore på utveksling $\mathrm{i}$ Warszawa. ${ }^{10}$

Personane som kom i i 970, var utplukka frå flyktningleirar i Italia (Latina-leiren utanfor Roma) og Austerrike (Traiskirchenleiren ved Wien). Dette var personar som var stranda i flyktningleirane. UDs arkiv fortel lite om desse. Eg har ikkje klart å finna personar frå denne gruppa som ville la seg intervjua. Derfor gir medieomtalen frå samtida det beste biletet av denne innvandringa til Noreg, forutan Mendelsohn. Avisene spriker noko i (den i stor grad arbeidssentrerte) beskrivinga av desse flyktningane, men den første omtalen er av eit fly som landa på Fornebu Flyplass I r mai i 970. Polskjødiske flyktningar var ein liten del (nokre få) av ei gruppe på nokre titals austeuropeiske flyktningar i ulik fysisk forfatning. Avisene spriket

8 RA, C. Berg-Nielsen. Fortruleg melding for den norske ambassaden i Warszawa til UD. o8.09. I969.

9 RA, B. M. Alvegård. For ambassaden i Warszawa. Brev til UD. 02.I 2.I 969.

10 Intervju med Boleslaw Srebro I I.I 2.201 9. 
i talfestinga av flyktningane på flyet. Ei ny gruppe, beståande blant anna av nokre polske jødar, skulle komme 25. mai, men dette fekk ikkje nokon avisomtale i ettertid. ${ }^{11}$

\section{Aktørane}

\section{Myndigheiter og ikkje-statlege hjelpe- organisasjonar}

Hovudargumentet mitt er som nemnt at danske myndigheiter og deira NGO-samarbeidspartnarar på avgjerande stadium i prosessen var tidlegare enn deira norske motpartar i deira aktive forsøk på å få polske jødar til å komme. Dei viktigaste samarbeidspartnarane var Norsk Flyktningehjelp og Dansk Flyktninghjelp. Mønsteret starta frå første initiativ med Halvorsens brev. Dei norske mottakarane av brevet var UD-direktør Einar Ansteensen, viseformann i Arbeidarpartiet Reiulf Steen, direktør i Instituttet for fredsforsking Johan Galtung, og stortingsmann Gunnar Garbo. ${ }^{12}$ UDs arkiv viser at byråkratar i den norske utanrikstenesta blei irriterte på Halvorsen si uforsiktige spreiing av brevet, men valde likevel å involvere han i diskusjonar samtidig som dei utforska skandinavisk samarbeid om hjelpetiltak. UD avventa andre skandinaviske lands reaksjonar. ${ }^{13}$

Der norske myndigheiter avventa, bestemte danske myndigheiter seg for at polske jødar skulle få komme. Dei danske brevmottakarane var direktør for Utanriksminesteriet Paul Henning Fischer (ambassadør i Warszawa i r 960), utanrikspolitisk redaktør i

11 Meir utdjupa og diskutert i masteroppgåva (Larsen 2020).

12 RA, Dag Halvorsen brev («De polske jøders stilling og eventuelle hjelpetiltak frå skandinavisk side») i Utenriksdepartementets arkiv 06. Io.I968. Send frå Praha.

13 RA, E. F. Ofstad notat signert for UD, Rettsavdelinga I 4. I I.r 968.
Politikken John Danstrup, og fhv. stats- og utanriksminister Jens Otto Krag. Danmarks ambassadør i Warszawa John Knox konkluderte i eit brev til Utanriksministeriet 29. november I968 med at Danmark burde ta imot polskjødiske flyktningar. Knox anbefalte i brevet korleis Danmark «utifrå humanitære synspunkt kunne hjelpe dei polske jødane», sjølv om ein ikkje kunne gi noko anslag over kor mange polske jødar som i teorien ville ha interessa av å komme til landet. 25. februar I 969 følgde myndigheitene i Danmark etter. Det blei bestemt å gi polske jødar lett moglegheit til å søke om innreisemoglegheit til landet i eit møte i Justisministeriet. Både ambassaden og tilsynet med utlendingar ville forlate sedvanleg rutine og i staden framskynde behandlinga av visumbegjæringar. Det blei slik bestemt å ta imot eit par hundre polske jødar og så ta situasjonen opp til vurdering igjen. Her blei det bestemt også å unngå medieomtale av migrasjonen av omsyn til det polsk-danske forholdet. Samtidig gjekk dei få polske jødane som søkte innreise til Noreg gjennom vanleg søknadsprosedyre. Danske myndigheiter samarbeidde med media om å unngå offentleg omtale av migrasjonen til landet, noko danske aviser følgde (Smedegaard Pedersen 2005: 27-30).

Noregs regjering, leia av Per Borten (Senterpartiet), si rolle i saka er kompleks og samansett. Bortsett frå seks veker i 1963 (Lyng-regjeringa) blei etterkrigs-Noreg leia av Arbeidarparti-regjeringar frå I945 til I 965 . Erfaringar frå tiåra etter andre verdskrig som verkja inn, særleg for det jødiske miljøet i Noreg, var derfor knytt til Arbeidarpartiregjeringar. Borten si borgarlege regjering overtok i I 965 med John Lyng (Høgre) som utanriksminister. Lyng fekk ei leiande rolle for dei norske reaksjonane på den antisemittiske kampanjen. Då temaet nådde Stortinget i mai I968, balanserte reaksjonane mellom utanrikspolitiske ambisjonar gjennom 
forholdet til Polen, og omsynet til menneskerettar. Her fastslo Lyng at antisemittisme var uakseptabelt og ikkje kunne unngå å påverke det norsk-polske forholdet negativt. ${ }^{14}$

Då håpet om å få polske myndigheiter til å avslutte kampanjen rant ut, begynte norske myndigheiter og samarbeidspartnarar å sjå på andre måtar å hjelpe råka polske jødar på. Først ein månad etter det danske vedtaket om å ta imot polskjødiske flyktningar, blei prosessen i Noreg driven vidare av Det Norske Flyktningeråd etter initiativ av sosialøkonomen Johan Vogt. Vogt sende Flyktningerådet eit brev 27. mars I969. Han førespurde om organisasjonen kunne informere han om kor mange polske jødar som var komne til Noreg, og om moglegheitene for at det kunne bli gitt innreiseløyve for fleire. ${ }^{15}$ Etter å ha sendt eit purrebrev, fekk Vogt svar av Wilhelm Bøe ro. april. Bøe skreiv at det berre hadde komme ei handfull polskjødiske flyktningar til Noreg til då. Flyktningerådet, som hadde vore i kontakt med fleire jødiske hjelpeorganisasjonar, meinte det ville vere best å få eit møte med fleire instansar. ${ }^{16}$

Norske myndigheiter forhøyrde seg i april om korleis DMT stilte seg til eit organisert kvoteflyktningmottak av polske jødar. Berit Reisel forstod det slik at det var ein føresetnad at DMT stilte seg positive for at Noreg skulle ta imot ein kontingent. Dette stilte DMT seg negativ til. ${ }^{17}$ Nokre dagar etter møtet formidla forstandar i DMT Harry Koritzinsky menigheten sitt svar til Kjell Kolding frå UD i ein telefonsamtale (Paszkiewicz 2020).

14 Stortingsforhandlinger I 967-I 968: 4004 .

15 RA, Johan Vogt. Brev til Det Norske Flyktningeråd. 27.03.1 969 .

16 RA, Wilhem Bøe. Brev på vegne av Det Norske Flyktningeråd til Johan Vogt. I0.04. I969.

17 Intervju med Berit Reisel o2.03.2020.
Trass åtvaringar frå UD om potensielle komplikasjonar engasjerte Flyktnigerådet JDC til å halde eit møte. Visedirektør i JDC Ted Feder skulle komme til Oslo for å halde eit informasjonsmøte 20. mai om potensielle hjelpetiltak for blant anna polsk jødar. ${ }^{18}$ Personar frå regjeringa, Stortinget, DMT og andre samfunnsinstitusjonar blei inviterte til møtet.

På slutten av I969 starta myndigheitene planlegging av eit mottak av polskjødiske flyktningar organisert av Flyktningerådet. På dette tidspunktet var det snakk om jødar som hadde forlat Polen og opphelde seg mellombels i flyktningleirar i Wien og Roma. Første teikn på slik planlegging fann eg i eit brev 4. desember frå Sosialdepartementet der UD blei oppmoda om å sende ein eller fleire representantar til eit møte i 8. desember. På dette møtet dei blei det bestemt å ta inn opp til r oo flyktningar i Noreg året etter. Dette var snakk om ei gruppe funksjonshemma- og ei gruppe arbeidsføre flyktningar som oppheldt seg i Austerrike og Italia. ${ }^{19}$ I januar I 970 begynte Flyktningerådet å uttala seg om planar for eit slikt mottak i media. Bøe uttala i Morgenbladet 26. januar at Flyktningerådet tok sikte på å gi cirka 200 jødiske polakkar opphald i Noreg fortast mogleg. ${ }^{20}$ Organisasjonen hadde gjennom prosessen nær kontakt med myndigheiter, andre hjelpeorganisasjonar, og DMT.

Eit eige kvotemottak av polsk jødiske flyktningar blei aldri gjennomført, truleg grunna DMT si avvising året før. Likevel kom nokre titals frå flyktningleirar som ein del av

$18 \mathrm{JMO}$, Wilhem Bøe. Brev på vegne av Det norske flyktningeråd til Harry Koritzinsky. I4.05. I969.

19 RA, Notat signert av Olav BucherJohannessen for UD. 5. politiske kontor. 29.I 2.1969.

20 Morgenbladet 26.or.I 970: I2. 
eit større mottak av austeuropeiske flyktningar i mai i 970. Eit samrøysta Storting løyvde 20. mars I 970 to millionar kroner til flyktninghjelp og bustadtiltak for nye flyktningar til Noreg. Ifølgje Halfdan Hegtun (Venstre) sine beskrivingar gjaldt dette polske flyktningar av jødisk slekt, samt flyktningar frå Tsjekkoslovakia. ${ }^{21}$ Dette finansierte truleg mottaket i mai der Flyktningerådet hadde ansvar for dei etter tilkomst. Organisasjonen skulle prøve å skaffe flyktningane hyblar og småleilegheiter. ${ }^{22}$ Myndigheitene kommuniserte tett med DMT og organisasjonar som Flyktningerådet. Myndigheitene sin innsats kunne ført til at fleire polskjødiske flyktningar kom til Noreg slik det blei førespegla i slutten av i 969 og starten av i 970. DMT si avvising av førespurnaden om eit kvotemottak gjorde det unaturleg for myndigheitene å trasse dette.

Flyktningerådet sin innsats var avgjerande for at det til slutt kom nokre få polske jødar frå flyktningleirar i mai i 970, og kunne potensielt ført til at talet nådde hundretals. Likevel var ikkje deira innsats like stor som den ekstraordinære innsatsen til deira danske søsterorganisasjon. Professor i kultur- og språkmøtestudiar Garbi Schmidt meinte at flyktningane fekk tilgang til Danmark ikkje minst på grunna Dansk Flyktninghjelp sin innblanding. Formann i hjelpeorganisasjonen Isi Foighel appellerte til den danske regjeringa om at ein ikkje - via stigande restriksjonar overfor flyktningar - skulle gjentaka den skjebnesvangre politikken frå r930-talet overfor jødiske flyktningar (Schmidt 2015: 226). Dansk Flyktninghjelp fekk ei viktig rolle gjennom blant anna innkvartering av flyktningane då trykket var på sitt høgaste hausten I 969 .

\footnotetext{
21 Stortingsforhandlinger I 969-1970: $2234^{-2} 235$.

22 Aftenposten I 2.05.1970: 2.
}

\section{Jødiske miljø}

Dei jødiske miljøa i landa spelte ei rolle i at det kom langt fleire polskjødiske flyktningar til Danmark enn Noreg. Det jødiske miljøet i Danmark var i utgangspunktet langt større enn det norske, dessutan blei dei danske jødane i hovudsak redda over til Sverige under andre verdskrig. Dei danske jødane sin økonomi blei heller ikkje likvidert slik tilfellet var for dei norske jødane. Det Mosaiske Troessamfund (sidan 20 4 Det Jødiske Samfund i Danmark) var Danmarks største jødiske menighet. Bent Melchior overtok som menigheten sin overrabbinar etter faren døydde i desember 1969. Melchior beskreiv sitt og menigheten sine møte med flyktningane i sjølvbiografien $S a$ valg da livet ( I 997). Melchior meinte det var opplagt at menighet måtte spele ei viktig rolle $\mathrm{i}$ integrasjonen av flyktningane i Danmark. Han lova seg sjølv å gjere sitt ytste for at det han omtala som berettiga kritikk av mottakinga av tidlegare innvandringsbølgjer ikkje skulle gjentakast denne gongen. Som del av sin innsats for flyktningane laga menigheten arrangement i møtelokala sine kvar søndag. Menigheten etablerte også eit program der polskjødiske familiar fekk ein danskjødisk kontakfamilie. Trass $\mathrm{i}$ at programmet skapte nokre varige vennskap, meinte Melchior det ikkje var ein eintydig suksess (Melchior 1997: I 16 , I $24-$ I30).

Det jødiske miljøet i Noreg i etterkrigstiåra var lite og sterkt prega av Holocaust. Kor hardt tragediane sat i speglast i det første ordet Reisel nemnde på spørsmål om kva som opptok det jødiske miljøet i Noreg over 20 år seinare: «overleve». ${ }^{23}$ Historikaren Vibeke Kieding Banik beskreiv at jødane leid urettferdigheit under det økonomiske etterkrigsoppgjeret, og at det ikkje blei teke omsyn til dei ekstra vanskane jødane hadde

23 Intervju med Berit Reisel o2.03.2020. 
når dei skulle reetablere seg. Dette gjaldt både bustad, arbeidsplassar, og gjenetablering av eit jødisk miljø (Kieding Banik 2009: I 26-I 27). Mendelsohn rekna seg fram til at det var cirka I Ioo jødar i Noreg i I 970 (Mendelsohn I986: 423). Erfaringane frå mottaket på I940-talet spelte ei rolle då spørsmålet om eit potensielt mottak av polskjødiske flyktningar kom opp i DMT i r 969, sjølv om føresetnadane var ulike.

\section{Avgjerande hendingar}

\section{Førespurnaden til DMT}

Då førespurnaden om korleis menigheten stilte seg til om det skulle gjerast eit kvotemottak av polskjødiske flyktningar frå myndigheitene til DMT kom, stilte menighetsstyret seg negative. Reisel jobba frå innsida saman med andre i Jødisk Studentklubb for å få styret til å endre meining, utan å lykkast. Ungdomane kjempa for å ta inn polskjødiske flyktningar til Noreg med å vise til dei positive erfaringane frå Danmark og Sverige, samt kor lite det jødiske miljøet i Noreg var. Spurd om styret sine motargument, fortalde Reisel at dei meinte det ville bli for omfattande og krevjande. Dei var først og fremst redde for oppblomstring av antisemittisme. Dette fordi flyktningane ville bli synlege. Dei polske jødane var «annleis», snakka eit anna språk, og mange av dei var sikkert ideologiske kommunistar, noko det var redsel for. ${ }^{24}$ Møtet blei halde i slutten av april r 969 (Paszkiewicz 2020).

Reisel forklarte i ei utgreiing menighetsleiinga sin bakgrunn og viktige erfaringar då spørsmålet om eventuelt å mottaka polskjødiske flyktningar kom:

24 Intervju med Berit Reisel 02.03.2020.
Menighetsleiinga var overlevande frå krigen. Nokre hadde overlevd leirar, mens andre hadde vore flyktningar i Sverige. Så hadde dei levd gjennom etterkrigsoppgjeret (der det jødiske miljøet fekk svært lite).

Det var harde kår for den overlevande minoriteten. Norske myndigheiter fekk eit internasjonalt krav om å ta inn like mange jødar som hadde døydd. Det skjedde ikkje. Dei jødane som til slutt fekk innvilga sine søknadar om å komme til Noreg, hadde ein yrkesprofil Noreg trong til gjenoppbyggingsarbeid. Menigheten måtte garantere for dei økonomisk. Det hadde menigheten ikkje midlar til, så internasjonale jødiske organisasjonar som JDC måtte bidra. Eit anna problem var at dei blei spreidde over heile landet. Dette var eit stort problem for familiane det gjaldt og menigheten. Familiane trong eit fellesskap, men staten ønskte å integrere dei i storsamfunnet for å unngå «gettofisering». Det som var vanskeleg for menigheten, var at dei dreiv eit outreach-program med kultur og religiøse ritual. Det var vanskeleg å få til med økonomien som ikkje fanst. Dei hadde dårleg erfaring med å bringe inn grupper av jødiske flyktningar fordi myndigheitene hadde ein policy som gjorde dette vanskeleg for menigheten. Eksempelvis med «minusflyktningar» (sjuke flyktningar grunna krigen) som menigheten måtte garantere for økonomisk. (Intervju med Berit Reisel 04.03.2020).

Økonomisk ansvar blei også eit tema i 1969. I eit intervju i forbinding med Paszkiewicz sin artikkel, uttala Reisel at DMT blei førespegla å stille slike garantiar for polskjødiske flyktningar, og at det blei antyda ein kostnad per person (Paszkiewicz 2020). Rekneskap frå Den Jødiske Sosialnemnd viser at DMT stilte garantiar for såkalla «flyktninglån» minst fram til I963, då elleve 
flyktningar fekk garantiar frå 3000 til 8000 kroner. 25

\section{Kor avgjerande var DMT sitt nei?}

DMT si avvising har blitt sett på som hovudårsak til den manglande polskjødiske migrasjonen til Noreg, blant dei få personane tilknytte det jødiske miljøet i Noreg med kjennskap til temaet. Det er ingen tvil om at avvisinga førte til at det kom færre polskjødiske flyktningar til Noreg. Også eit seinare planlagd organisert mottaket av opp mot 200 polskjødiske flyktningar frå flyktningleirar i 1970 blei skrinlagt, og berre nokre få kom som ein del av eit større austeuropeisk mottak. Eit slikt mottak kunne, om integreringa lykkast og det ryktast i leirane, ha ført til at enda fleire polske jødar kom til Noreg gjennom nettverksmigrasjon. Dette ville ha fungert som pull-faktorar for å få polskjødiske flyktningar til Noreg. Likevel er det usannsynleg at migrasjonen kunne nådd dansk nivå på 2600. At Reisel kunne referere til kor vellykka effekt polskjødisk migrasjon hadde hatt på dei jødiske miljøa i Danmark og Sverige, tyder på at ein del av grunnlaget for den store migrasjonen til desse landa allereie var lagt. Talet kunne truleg ikkje nådd danske høgder, men kanskje litt fleire enn dei føreslådde 200.

\section{Det polske varselet om utreisestans}

Som reaksjon på varselet om utreisestans for polske jødar sommaren I 969 gjekk Danmark over til å gi automatisk visum til alle jødiske søkjarar ved ambassaden i Warszawa (Smedegaard Pedersen 2005: 28). Eit internt notat viser at norske UD mottek eit notat 12 . juni, tre dagar etter varselet, om den danske

25 OBA, Namnlaus oversikt over garantiar i Den Norske Creditbank i Harry Koritzinskys privatarkiv o7.1 I.1963. politikkendringa frå Danmarks ambassade i Warszawa. Notatet opplyste at Danmarks ambassade fekk myndigheit til å betale reisa for dei som måtte ha behov for det. ${ }^{26}$ Følgeleg kom det ein straum polskjødiske flyktningar til Danmark. Smedegaard Pedersen talfesta at det kom cirka ıoo jødiske flyktningar frå Polen til Danmark kvar einaste veke i den mest hektiske perioden hausten I 969 , noko som førte til logistikkproblem. Som følgje av dette leigde Dansk Flyktninghjelp inn skipet St. Lawrence til å chartre flyktningane til København. Kor stor betydning varselet-, og dei politiske reaksjonane på det skulle få, var ikkje openbart for verken den norske- eller danske utanrikstenesta. Panikken innan det polskjødiske miljøet som Srebro beskreiv, og det auka emigrasjonstrykket fastslår viktigheita av varselet. Personar i den danske utanrikstenesta som kontorsjef Krog-Meyer, var ikkje sikre på kva følgjer fristen ville få då dei bestemte seg for å handle. Krog-Meyers notat frå 26. juni fastslo at det ikkje var mogleg å avgjere om fristen ville medføre eit større jødisk utreisepress frå Polen til Danmark (Smedegaard Pedersen 2005: 2-4, 28).

Danmarks politikkendring sende eit klart signal til polske jødar om moglegheita til å komme til landet. Boleslaw Srebro si beskriving av at Sverige og Danmark «opna dørene» for jødiske migrantar frå Polen etter varselet speglar ei oppfatning om opne grenser til Danmark blant polske jødar. ${ }^{27}$ Det kraftig aukande migrasjonstrykket til Danmark hausten 1969 gjer at eg kan fastslå at dette var eit avgjerande punkt. Dette var den kraftigaste pull-faktoren som trakk polske jødar til Danmark. Sverige følgde Danmarks reaksjon gjennom justeringar av sitt kvotesystem for polske jødar som fekk visum på ambassaden

26 RA, Notat signert av O. Bucher-Johannessen for UD. 5. politiske kontor. I 8.09.1 969.

27 Intervju med Boleslaw Srebro I I.r 2.20I 9. 
i Warszawa. 24. juli blei den svenske kvota utvida med 500 til i I 50 . Innan enda av juli nådde talet på polskjødiske flyktningar til Sverige I 29r. Auka i tal på innvilgar var i juli I 969 var med dette beviseleg slik historikaren Lukasz Gorniok beskreiv det (Gorniok 2016: I23).

Norske myndigheiter valde ei langt meir avventande tilnærming til varselet. Informasjon om varselet blei send frå Noregs ambassade i Warszawa I2. juni r969, og motteken i UD I 4. juni. 3. juli blei UD informert i eit notat frå Danmarks ambassade om deira politikkendring. Byråsjef i Statens Utlendingskontor Arnulf Jøraandstad meinte at før ein frå norsk side eventuelt skulle innføre liknande reglar, måtte saka inngåande drøftast med Justisdepartementet og Sosialdepartementet. UDs 5. politiske kontor vurderte at det ikkje var nødvendig å følgje Danmarks politikkendring. Dette fordi Noreg stod i ei anna stilling enn Danmark og Sverige som hadde det kontoret omtala som forholdsvis store jødiske «koloniar». Kontoret var likevel klart på at saker som gjaldt polske jødar måtte behandlast raskt og liberalt. Då det berre var komme I 5 søknadar I 5 . juli, meinte ambassaden at det truleg ikkje kom til å bli nok søknadar innan fristen til at visumlettingar liknande dei danske ville bli nødvendige. Alle dei I 5 fekk innvilga visum, men eit ektepar måtte vente til 3. september. ${ }^{28}$ Synet på den danskjødiske minoriteten sin avgjerande viktigheit var framleis i live blant norske byråkratar, representert ved byråsjef Smedsrud i Justisdepartementet, i 8. desember. Då uttrykte han at han tvilte på at visummyndigheita Danmarks ambassade i Warszawa hadde fått var grunnen til at så mange polske jødar kom til landet. Smedsrud

28 RA, Notat signert av Olav BucherJohannessen for UD. 5 politiske kontor. I 8.09.1969.

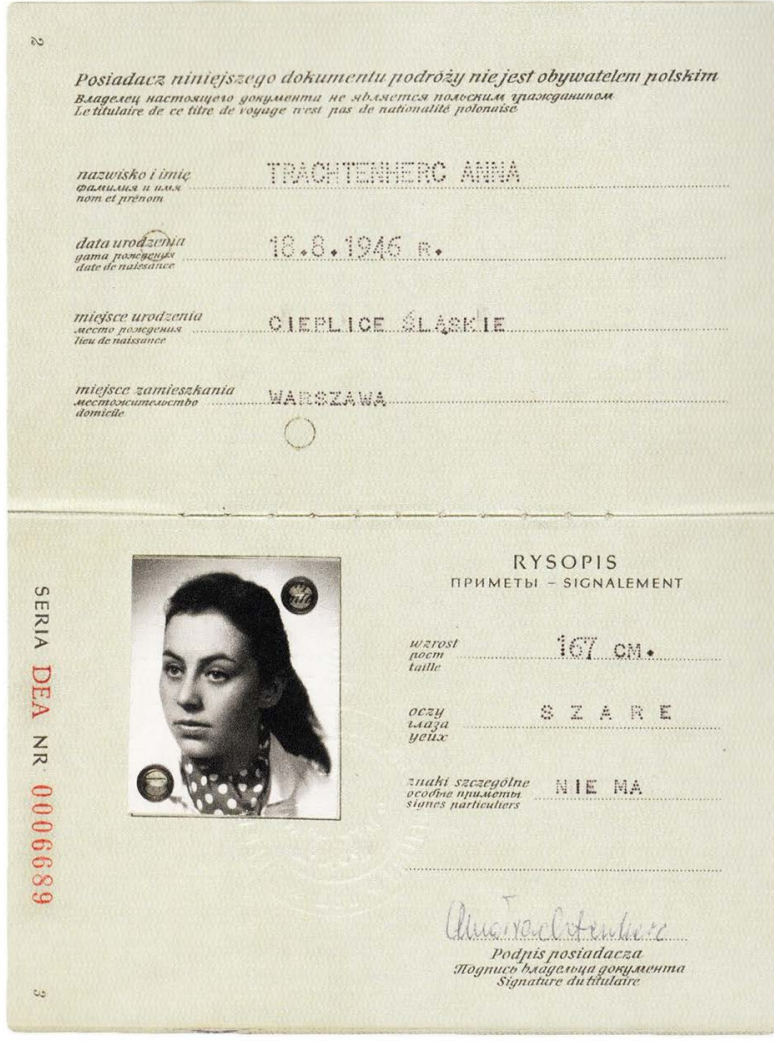

Polske jøder måtte erklære seg som sionistar, sei frå seg sitt polske statsborgarskap, og deretter få eit eingongsdokument, her illustrert med Anny Trachtenherc sitt, for å få forlate Polen. Då det blei varsla om stans i utskrivinga av slike sommaren 1969 eskalerte den jødiske emigrasjonen.

trudde grunnen var den store aktive jødiske «koloni» i Danmark. 29

Det må understrekast at DMT si avvising med stort sannsyn kan ha verka inn på byråkratane i utanrikstenesta sitt handlingsmønster, trass $i$ at dette ikkje er nemnt $i$ UDs arkiv. Særleg med tanke på at det var Kjell Kolding frå UD som fekk den første beskjeden om avvisinga.

Sjølv om den jødiske minoriteten i Danmark var langt større enn den i Noreg, og det

29 RA, Notat signert av O. Bucher-Johannessen for UD. 5 . politiske kontor. 29.I 2.1969. 
kan ha vore ein mindre faktor gjennom nettverksmigrasjon, kan eg konkludere med at norske byråkratar overvurderte denne faktoren. Majoriteten av emigrantane var sekulære og hadde liten tilknyting til jødisk religion. Dei var meir opptatt av at dei hadde mista framtidsutsiktene i Polen, og kva moglegheiter dei hadde til å skaffe seg nye. Derfor blei fristen og den danske opninga langt viktigare enn Smedsrud antok.

Varselet blei, i motsetnad til blant polske jødar, ikkje tatt fullstendig på alvor innan delar av Noregs utanriksteneste, noko som råka saksbehandlingstider. Dette råka ekteparet som måtte vente til etter fristen med å få visum. Arkivmateriale frå UD om saksbehandlinga av denne søknaden tyder på at situasjonen ikkje blei oppfatta akutt i heile utanrikstenesta. I. september I 969 konfronterte Olav Bucher-Johannessen Jøraandstad om ekteparet som hadde søkt 2o. juni si sak. Bucher-Johannessen spurte kvifor saka, trass $i$ at UD hadde bede om at slike saker blei behandla hurtigast mogleg, ikkje var blitt avgjort i god tid før fristen. Jøraandstad, som var fullt klar over fristen, svara at saka ville bli behandla i Statens Utlendingsråd same ettermiddag. Jøraandstad forklarte at det grunna feriar og hans eigne «brekne skulder» ikkje hadde vore mogleg med møteinnkalling av Utlendingsrådet $\mathrm{i}$ august. Han fortalte også at han «trudde ikkje på tidsfristen I. september». Jøraandstad hadde vidare følt at han i dette tilfellet ikkje kunne gå utanom instruksen han hadde for behandling av slike saker. ${ }^{30}$ Trass $i$ at alle søknadane blei innvilga, sende ikkje denne trege saksbehandlinga signal om at det var fri innvandring til Noreg til polske jødar i ein dramatisk periode. Dette skapte eit

30 RA, Notat signert av Olav BucherJohannessen for UD. 5 . politiske kontor. 03.09.1969. avgjerande skile. Migrasjonsstraumen gjekk utan flyt til Noreg.

\section{Det planlagde leiruttaket i 1970}

Boka frå menighetsstyret med saks- og vedtaksoversikt frå styremøte viser at polskjødiske flyktningar blei diskutert på eit styremøte ıo. mars I 970. Dette i samband med eit brev frå Flyktningerådet 24. februar. Flyktningerådet spurde om DMT kunne løyve 2000 kroner i busettingsbidrag til ein polakk som skulle gifte seg. Styret stemte (fem mot to) mot å innvilge støtte fordi saksbehandlinga låg $i$ Den Jødiske Sosialnemnd (som ikkje hadde høyrt frå dei). ${ }^{31}$ Polskjødiske flyktningar blei vidare diskutert med referanse til saka Io. mars på eit møte 23. april: Fleirtalet i menighetsstyret meinte å ha løyvd 3000 kroner til Flyktningerådet i samband med arbeidet deira for polskjødiske flyktningar, men ville utsette disponeringa av beløpet til ein fekk nærmare oversikt over talet på jødiske flyktningar i leirane. ${ }^{32}$ Dette tyder på at styret innan 23. april forstod det ikkje kom så mange, og at førespurnaden var blitt behandla tidlegare. Det må ha skjedd noko mellom dei to styremøta sidan styret refererte til det første møtet, men referer til ein annan konklusjon. Kommunikasjonen i styret tyder på at Flytkningerådet, som var pådrivar og administrator for det planlagde mottaket, formidla myndigheitene sin førespurnad. Det er overveldande god grunn til å tru at DMT si avvising året før spelte ei avgjerande rolle for at det ikkje blei gjennomført eit organisert kvotemottak av polske jødar i det omfanget Flyktningerådet førespegla i media i januar I970.

31 DMT, Bok frå styret. Io.o3. I970.

32 DMT, Bok frå styret. 23.04. I 970. 


\section{Betydninga av funna}

Dei mest sentrale funna i undersøkinga er at DMT avviste eit statleg initiativ om å gjere eit organisert mottak av polskjødiske flyktningar, og at den norske utanrikstenesta inntok ei avventande haldning til polske jødar i r968 og 1969. Arkivmaterialet som viser at alle søkjarar fekk innvilga visum, samsvarar med Mendelsohns beskriving at Statens Utlendingskontor inntok ei liberal haldning til søknadane, men avventinga i tidlegare fasar gir eit breiare bilete. Funna mine fungerer som ein puslespelbit i den større norske innvandringshistoria under den kalde krigen. Omtalen av dei polskjødiske flyktningane fortel noko om norsk tilnærming til innvandrarar: sjølv flyktningar blei definert utifrå arbeidsstatusen sin, enten var dei arbeidsdyktige elles var dei handikappa. Dette fungerer som ein polert versjon av I940-talets «arbeidsflyktningar» og «minusflyktningar». Den passive tilnærminga gir ein indikasjon på kvifor innvandringa til Noreg forblei låg, trass god økonomi i samfunnet generelt, liberalt lovverk og -søknadsbehandlingar.

Som ein del av jødisk historie i Noreg er funna enda meir komplekse og sentrale. Dei fortel om ein manglande tryggleik blant norske jødar, særleg den Holocaust-overlevande generasjonen, overfor myndigheitene og storsamfunnet i r 969. Funna fortel også om eit interessant generasjonsskilje mellom den Holocaust-overlevande generasjonen i DMT-styret, og andregenerasjons Holocaust-overlevande som Reisel og Jødisk Studentklubb. Det har blitt skrive ein del faglitteratur om dette generasjonsskiljet i storsamfunnet med fokus på «68erne» og deira foreldre. Det har ikkje blitt skrive like mykje om generasjonsskiljet innan det jødiske miljøet, men Kieding Banik har vist at generasjonen som blei fødd rundt andre verdskrig i større grad såg på Israel som eit jødisk-kulturelt senter enn foreldregenerasjonen (Kieding Banik 2009: 264). Innan det jødiske miljøet i Noreg var Holocaust ein ekstra dimensjon. Mitt intervju med Reisel gav inntrykk av at det var ein stor respekt frå barna overfor foreldregenerasjonen, eksemplifisert av beskrivinga hennas av eit opent og nært forhold til styret. ${ }^{33}$ Funna gir også ein viktig grunn til at det små jødiske miljøet i Noreg ikkje hadde same vekst som det danske.

Eg har ikkje funne noko teikn på antisemittiske haldningar i norsk utanriksteneste relatert til den polskjødiske emigrasjonen i UDs arkiv eller andre kjelder. Det finst bruk av i 2020-kontekst utdatert terminologi som «koloni» om jødiske minoritetar, og ei saksmappe kalla «jødespørsmålet». Sidan det ikkje er teikn til antisemittisme i utsegnene til byråkratane, er det ikkje grunnlag for å hevda at utanrikstenesta var prega av antisemittisme. Ein kan stille spørsmål ved kvifor norske myndigheiter følte dei måtte involvere DMT i prosessen, men involvering av eksisterande minoritetsmiljø er ikkje uvanleg ved gjennomføring av flyktningmottak. Om dette også gjeld krav om økonomisk ansvar bør undersøkjast nærmare. Den manglande involveringa av DMT i planlegginga av mottaket på i 940-talet, fungerte dårleg, noko som truleg var i myndigheitene si bevisstheit i I 969. Det er slik eg vurderer det naturleg å setje den norsk utanrikstenesta si avventande tilnærming til polske jødar i I 968 og r 969 i samanheng med den generelle tilnærminga til flyktningar i etterkrigstida der ein først prioriterte hjelp i nærområdet, eksemplifisert med tilnærminga til ungarske flyktningar. Andre vil potensielt sette den avventande tilnærminga i samanheng med manglande forståing av jødisk liding, og slik som ei fortsetting

33 Intervju Berit Reisel o2.03.2020. 
av neglisjeringa av norske jødar under etterkrigsoppgjeret. Dette er etter mi oppfatning ein så sterk påstand at den vil trenge langt meir datamateriale som bevis, truleg frå andre cases, for å male eit større mønster som avvik så kraftig frå norsk sjølvbilete som eit tolerant land. DMT si avvising gjer dette lite truleg.

\section{Svein-Erik Larsen er} ein nyutdanna norsk historikar. Han fullførte ein mastergrad ved Universitet i Bergen våren 2020. Han har også fullført ein bachelorgrad i samanliknande politikk ved same universitet våren 2016, der han skreiv bacheloroppgåve om valsystem sin påverknad

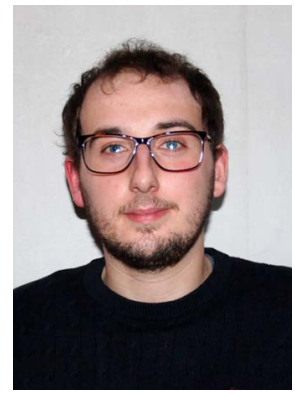
på regjeringsdanning.

Etter å ha skrive historie-bacheloroppgåve om migrasjon til Vest-Tyskland og Frankrike dei første etterkrigstiåra, spissa han masteroppgåva si, som artikkelen er basert på, inn på jødisk migrasjon til Noreg i forbinding med emigrasjonsbølgja frå Polen 1968-1970.

\section{Kjelder}

\section{Arkivkjelder}

\section{Det Mosaiske Trossamfund i Oslo (DMT)}

Bok frå styret. 1968-I970.

Jodisk Museum i Oslo (JMO)

Det Mossaiske Trosamfund Korrespondansebrev:

Bøe, Wilhem S. Brev på vegne av Det Norske Flyktningeråd til Harry Koritzinsky.

$$
\text { I 4.05. I } 969 \text {. }
$$

Oslo byarkiv (OBA)

Looo5 - Det Mosaiske Trossamfund. I 939-1986.

OBA/A-I I 023 /F/Looo5.

Namnlaus oversikt over garantiar i

Den Norske Creditbank i Harry

Koritzinskys privatarkiv. 07.10.1963.

Riksarkivet i Oslo (RA)

Mappe: AJDC (American Joint Distribution Committee): Polske jøder. Del av Det Norske Flyktningeråd, saksarkiv. Periode: I 969. RA/ PA-I 254/D/Db/Loo64/ooo8:

Bøe, Wilhelm S. Brev på vegne av Det norske Flyktningeråd til Johan Vogt. I0.04.1969.

Vogt, Johan. Brev til Det Norske Flyktningeråd. 27.03.1969.
Mappe: Innvandring av jøder. Del av Utenriksdepartementet, hovedarkiv, saksarkiv. Periode: I 969-I 970. RA/S-6794/D/Da/Dad/ $\mathrm{L}_{3} 6 \mathrm{I} 6 / 0002$ :

Alvegård, B. M. Brev for den norske ambassaden i Warszawa til UD. O2.I2.69.

Berg-Nielsen, Christian. Fortruleg melding for den norske ambassaden $\mathrm{i}$ Warszawa til UD. 08.09.1 969.

Bucher-Johannessen, Olav. Notat signert for UD. 5. politiske kontor. 03.09.1969.

Bucher-Johannessen, Olav. Notat signert for UD. 5. politiske kontor. I8.09. I 969 .

Bucher-Johannessen, Olav. Notat signert for UD. 5. politiske kontor. 29.12.1969.

Mappe: Jødespørsmålet. Del av

Utenriksdepartementet, saksarkiv. Periode I 963-r 969. RA/S-6794/D/Da/Daa/ Lo575/ooor:

Halvorsen, Dag. Brev. Send frå Praha. o6.ro.r 968.

Ofstad, E.F. Notat signert for UD, Rettsavdelinga. I 4.I I.r 968.

\section{Aviser}

Aftemposten, I 2.05.1 970.

Arbeiderbladet 24.09. I969.

Arbeiderbladet, 2 I.05.I 970.

Morgenbladet, 26.0 I. I970.

\section{Intervju}

Reisel, Berit. 02.03.2020.

Srebro, Boleslaw. I I.I 2.20I9.

\section{Stortingsforhandlinger}

Stortingsmøte 30.05.1968, <https:// stortinget.no/no/Saker-og-publikasjoner/ Stortingsforhandlinger/Lesevisning/?p= $1967-$ 68\&paid $=7 \& w i d=a \& p s i d=D I V L 974 \& p g i d$ $=c \_0672 \& v t=c \& d i d=D I V L i o 7>$ (lasta opp 09.02 .2019 ).

Stortingsmøte 20.03.1970. «Forhandlinger i Stortinget nr. 280», <https://www. stortinget.no/no/Saker-og-publikasjoner/ Stortingsforhandlinger/Lesevisning/?p= 1969 70\&paid $=7 \& w i d=a \& p s i d=D I V L 953 \&$ pgid =b_0867\&vt=b\&did=DIVLI6 $>$ (lasta opp 28.08.2019). 


\section{Litteraturliste}

Academia. 202 I. «Dariusz Stola: curriculum vitae», Academia.edu, <https:// pan-pl.academia.edu/DariuszStola/ CurriculumVitae> (lasta opp 20.1 I.2019).

Andresen, Astri, Sissel Rosland, Teemu Ryymin, og Svein Atle Skålevåg. 20 I 5. Å gripe fortida - Innføring i historisk forståing og metode, 2. utgåve (Oslo: Det norske samlaget).

Brochmann, Grete, og Knut Kjeldstadli. 20 I4. Innvandringen til Norge 900-2010 (Oslo: Pax).

Castles, Stephen, Hein De Haas, og Mark J. Miller. 20I 4. The Age of Migration: International Population Movements in the Modern World, 5 . utgåve (Houndmills: Palgrave Macmillan).

Corell, Synne. 2000. «Vårt lille plaster på krigens sår. Norges mottak av jødiske «displaced persons» ot arbeidere mellom I 946 og I 950», hovedoppgave i historie, Universitetet i Oslo.

Gansinger, Simon. 201 9. «Configurations of antisemitism: the anti-Zionist campaign in Poland I968», i Anti-Zionism and Antisemitism: The Dynamics of Delegitimization, Alvin H. Rosenfeld (Bloomington: Indiana University Press), $34 \mathrm{I}-362$.

Gorniok, Lukasz. 2016. «Swedish refugee policymaking in transition? Czechoslovaks and Polish Jews in Sweden, I 968-1 972», doctoral dissertation, Department of Historical, Philosophical and Religious Studies, Umeå University.

Kieding Banik, Vibeke. 2009. «Solidaritet og tilhørighet - Norske jøders forhold til Israel 1945-1975", doktoravhandling. Det humanistiske fakultet, Universitet i Oslo.

Knoema. 2020. «Historical GDP per capita by country: statistics from the World Bank, I 960-20 I 8, Knoema [nettside], <https:// knoema.com/jesoqmb/historical-gdp-percapita-by-country-statistics-from-the-worldbank-1 960-201 8> (lasta opp I I.04.2020).

Larsen, Svein-Erik. 2020. «Noreg og dei polskjødiske flyktningane, I 968-I970», master thesis, University of Bergen, <https://bora. uib.no/bora-xmlui/handle/r 956/22428>.

Lorenz, Einhart. 2006. Bokmelding om Knut Kjeldstadli, Hallvard Tjemelang og Grete Brochmanns bok Norsk innvandringshistorie. Bd 3. I globaliseringens tid 1940-2000, frå 2003, Historisk tidsskrift 85(I): $133-136$.
Melchior, Bent. I 997. Så valg da livet (København: Palatino, NB PrePress).

Mendelsohn, Oskar. I986. Jødenes historie i Norge gjennom $300 \mathrm{a} r$, 2. utg. (Oslo: Universitetsforlag).

NAV. 2019. «Historisk statistikk om arbeidsmarkedet», NAV, or.I 2.20 9 (sist endra 20.02.2020), <https://www.nav.no/no/ nav-og-samfunn/statistikk/arbeidssokere-ogstillinger-statistikk/historisk-statistikk > (lasta opp I 2.04.2020).

Paszkiewicz, Zofia. 2020. «ødene Norge ikke ønsket», NRK, 2 I.I I.2020, <https://www. nrk.no/dokumentar/xl/jodene-norge-ikkeonsket-I.I 5 I43 I30> (lasta opp 2I.II.2020).

Rømming, Ellen. 201 8. «De norske jødenes skjebne», HL-sentret, I I. I 2.20 I 8 , sist oppdatert OI.I I.20I9, <https://www. hlsenteret.no/utstillinger/permanentutstilling/de-norske-jodenes-skjebneunder-andre-verdenskrig.html> (lasta opp 04.02.2020).

Schmidt, Garbi. 201 5. Norrebros Indvandringshistorie 1885-2010 (Københavns Universitet: Museum Tusculanum Forlag).

Smedegaard Pedersen, Rikke. 2005. «Jøders flugt fra ufred i Polen til fristed i Danmark . En undersøgelse af de polsk-jødiske flygtninge I 969-73", kandidatspeciale, Det humanistiske fakultet, Universitet I København.

Stola, Dariusz. 201 7. «Jewish emigration from communist Poland: the decline of Polish Jewry in the aftermath of the Holocaust», East European Jewish Affairs, $47(2-3)$ : I69-188, doi: <https://doi.org/ro.1080/I350 I $674.2017 .1398446>$.

Tangestuen, Mats. 2020. «Synagogen som levde i 2 I år», Jødisk museum [nettside], <https:// www.jodiskmuseumoslo.no/bygningenshistorie> (lasta opp 27.04.2020).

Vekony Olsen, Heidi Cecilie. 20I6. «Utforming og gjennomføring av norsk humanitær hjelp etter opprøret i Ungarn, I 956-I 957», masteroppgåve i historie, Universitet i Oslo. 